\title{
Development of Glycine Receptor Distribution in the Lateral Superior Olive of the Gerbil
}

\author{
Dan H. Sanes and G. Frederick Wooten \\ Departments of Neuroscience, Otolaryngology, and Neurology, University of Virginia Medical Center, Charlottesville, \\ Virginia 22908
}

\begin{abstract}
The concentration and relative distribution of glycine receptors were determined for the gerbil lateral superior olive at several postnatal ages. Quantitative autoradiographic techniques revealed significant ${ }^{3} \mathrm{H}$-strychnine binding to all regions of the nucleus from 4 to $90 \mathrm{~d}$. However, during the first $20 \mathrm{~d}$, a nonuniform distribution of binding emerged, such that the greatest concentration of receptor was found in the highfrequency region of the nucleus. An analysis of neuron packing density showed an approximate 2-fold distribution along the same axis at all ages. This evidence is consistent with an elimination of glycine receptors in the ventral region of the lateral superior olive as maturation progresses.
\end{abstract}

Knowledge of the ontogeny and distribution of a neuroreceptor molecule may afford useful information about a dynamic stage of synapse formation (Purves and Lichtman, 1985). Such knowledge may provide an intuitive correlate to function and should predict the anatomical distribution of the appropriate afferent terminals. As part of an effort to describe the development of a central inhibitory pathway, we have studied the quantitative distribution of its receptor molecule, the glycine receptor, during postnatal maturation. The lateral superior olive (LSO) is a brain stem auditory structure that receives an excitatory connection activated by ipsilateral sound stimuli, and an inhibitory connection activated by contralateral sound stimuli (Boudreau and Tsuchitani, 1968). The group of neurons that most likely mediates this inhibition is located in the medial nucleus of the trapezoid body (MNTB), a glycine-containing projection nucleus (Morest and Jean-Baptiste, 1975; Glendenning et al., 1985; Spangler et al., 1985; Campistron et al., 1986). There is both electrophysiological and autoradiographic cvidence implicating glycinergic inhibitory transmission in the LSO (Zarbin et al., 1981; Moore and Caspary, 1983; Sanes et al., 1985, 1987; Schwartz, 1985).

Our previous results demonstrated a nonuniform distribution of the glycine receptor along the tonotopic axis of the gerbil LSO (Sanes et al., 1985, 1987), such that the high-frequency region was the site of maximum concentration. There is one anatomical study in the cat that indicates a denser MNTB arborization in

\footnotetext{
Received Dec. 17, 1986; revised May 14, 1987; accepted May 20, 1987.

This work was supported by National Institutes of Health Grants NS 15478, NS 07462, and DA 03787, as well as by the Mary Anderson Harrison Endowment of the University of Virginia. We thank Dr. W. A. Geary for technical assistance and helpful discussions, and Rose Powell for the preparation of the manuscript.

Correspondence should be addressed to Dan H. Sanes, Departments of Otolaryngology and Physiology and Biophysics, NYU Medical Center, 550 First Ave., New York, NY 10016.

Copyright C 1987 Society for Neuroscience $0270-6474 / 87 / 113803-09 \$ 02.00 / 0$
}

the high-frequency region (i.e., medial limb) of the LSO (Glendenning et al., 1985). We have also noted a greater density of neuronal somas in the high-frequency region of LSO, but this did not necessarily account for the magnitude of the receptor gradient (Sanes et al., 1987). Given such a distinct anatomical distribution of the glycine receptor, it was of interest to follow its formation during postnatal maturation.

The gerbil auditory system develops to an adultlike state over the first $18 \mathrm{~d}$ postnatal. Sound is first capable of eliciting a neural response at $12 \mathrm{~d}$, and thresholds are within a mature range $6 \mathrm{~d}$ later (Woolf and Ryan, 1985). Although the maximum discharge rate of neurons in the ventral cochlear nucleus continues to increase until $30+d$, the mature dynamic range is reached by $18 \mathrm{~d}$ (Woolf and Ryan, 1985). The frequency tuning of these neurons is adultlike from 12 to $16 \mathrm{~d}$, depending on the frequency range (Woolf and Ryan, 1985). However, we have found that neurons located in the LSO, one synapse further in the auditory pathway, do not show adultlike dynamic ranges or frequencytuning properties at 15-16 d postnatal (Sanes and Rubel, in press).

The present experiment assayed for glycine receptor concentration and distribution using quantitative autoradiographic techniques to localize ${ }^{3} \mathrm{H}$-strychnine (SN) in the developing gerbil LSO (Geary et al., 1985). Strychnine has previously been shown to be a potent physiological antagonist and high-affinity ligand at glycinergic synapses (Curtis et al., 1971; Young and Snyder, 1973; Zarbin et al., 1981). We found that the pattern of receptor accumulation led from an initial state of uniform binding to a progressive appearance of the nonuniform glycine receptor distribution seen in adult animals.

\section{Materials and Methods}

Tissue preparation. Male and female gerbils (Meriones unguiculatus) that were born and raised to ages 4-21 d in our breeding colony were first anesthetized with sodium pentabarbitol $(30-55 \mathrm{mg} / \mathrm{kg}$, i.p.) and decapitated. The brains were rapidly removed from the skull and immersed in liquid Freon for $20 \mathrm{sec}$. The frozen tissue was stored at $-80^{\circ} \mathrm{C}$ or immediately mounted for cryostat sectioning. Serial sections were cut at $20-40 \mu \mathrm{m}$, thaw-mounted onto gelatin or poly-D-lysine-coated coverslips, and immediately placed within the confines of the cryostat $\left(-16^{\circ} \mathrm{C}\right)$. Sections were stored for no more than $6 \mathrm{~d}$ at $-35^{\circ} \mathrm{C}$ before use.

Quantitative autoradiography. The equilibrium conditions used for incubation of tissue sections were determined from previous kinetic experiments on ${ }^{3} \mathrm{H}-\mathrm{SN}$ binding in the absence (i.e., total binding) or presence (i.e., nonspecific binding) of $10^{-2} \mathrm{M}$ glycine. Tissue sections to be used for autoradiographic determination of glycine receptor concentration were first air-dried for $40 \mathrm{~min}$, and preincubated in PBS $(20 \mathrm{mM}$ $\mathrm{NaHPO}_{4}, 2 \mathrm{~mm} \mathrm{NaH} \mathrm{PO}_{4}, 150 \mathrm{~mm} \mathrm{NaCl}, \mathrm{pH} 7.4$ ) for 20 min, allowing endogenous ligand (e.g., glycine) to dissociate. This and all other solutions were kept at $4^{\circ} \mathrm{C}$. After preincubation in PBS, the sections were 


\section{1 day}

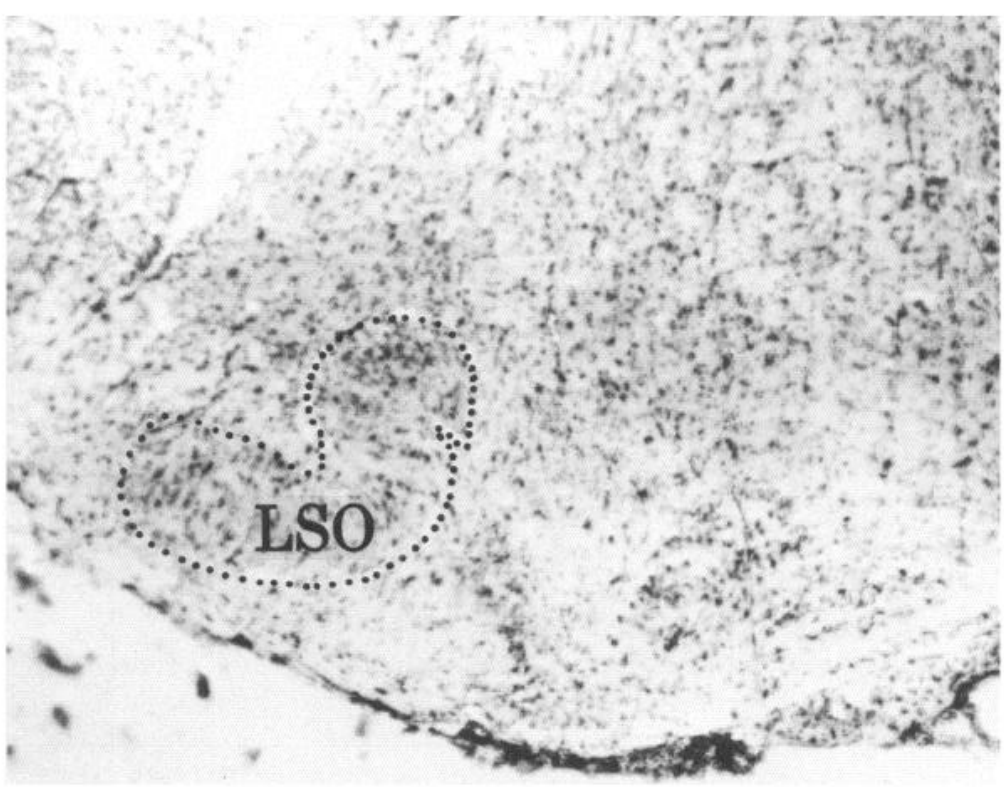

Figure 1. Representative image for ${ }^{3} \mathrm{H}-$ SN binding distribution in the lateral superior olive of a $21 \mathrm{~d}$ animal. The Nissl-stained section (top) and autoradiogram of total binding (bottom) are shown. The LSO is delineated in the Nissl section. In the total-binding section, the high-frequency region (arrow) and low-frequency region (arrowhead) are indicated. As is true for the adult, ${ }^{3} \mathrm{H}-\mathrm{SN}$ binding is relatively greater in the high-frequency region. LSO, Lateral superior olive. Calibration bar, 200 $\mu \mathrm{m}$.

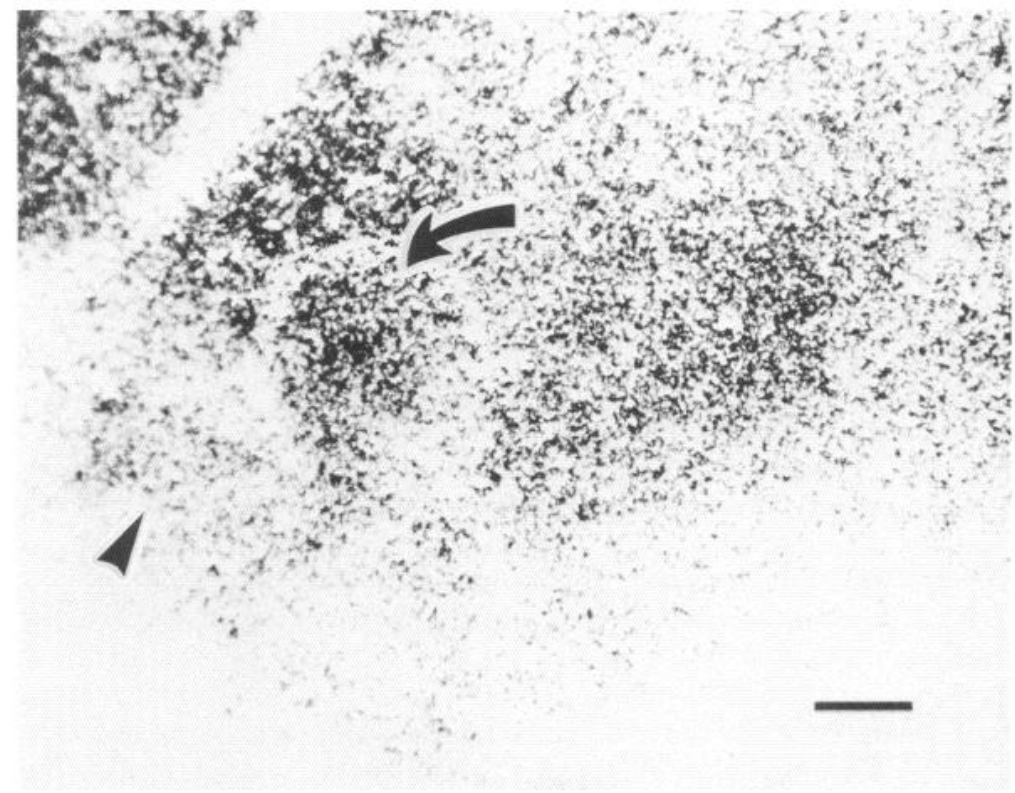

transferred to a solution containing $10 \mathrm{nM}^{3} \mathrm{H}-\mathrm{SN}$ with or without $10^{-2}$ M glycine for $20 \mathrm{~min}$. They were then rinsed in PBS for $5 \mathrm{sec}$, dipped in $\mathrm{dH}_{2} \mathrm{O}$, and rapidly air-dried.

The dry SN-bound sections were then apposed to LKB Ultrofilm for 4-5 weeks. The film was analyzed densitometrically on a Leitz MPV Microdot densitometer with an adjustable aperture. In addition to the tissue sections, each film was exposed to calibrated tritium-containing plastic standards (Amersham). Thus, a specific optical density (OD) measurement was equivalent to a value expressed as $\mathrm{nCi} / \mathrm{mg}$ tissue wet weight (Geary et al., 1985). A final concentration was computed by multiplying this quantity by the inverse of the ligand's specific activity:

$$
\frac{X \mathrm{nCi}}{\mathrm{mg} \text { wet weight }} \cdot \frac{\mathrm{fmol}}{Y \mathrm{nCi}}=\frac{\mathrm{fmol}}{\mathrm{mg} \text { wet weight }} \text {. }
$$

The ODs obtained from sections incubated in the presence of cold glycine were subtracted from the ODs from sections incubated in ${ }^{3} \mathrm{H}$ $\mathrm{SN}$ alone to yield values for specific binding.
Autoabsorption. The extent to which tissue prevented the tritium signal from reaching LKB film was determined. Animals of 4 and $11 \mathrm{~d}$ postnatal were injected interperitoneally with 75 and $125 \mathrm{nCi}$ of ${ }^{3} \mathrm{H}-2$ deoxy-D-glucose, respectively (New England Nuclear; $30.2 \mathrm{Ci} / \mathrm{mmol}$ ). Following a 45 min survival period, animals were anesthetized, decapitated, and the brain rapidly removed and frozen. Cryostat sections through the LSO were mounted on coverslips and air-dried. Alternate sections were extracted in $500 \mathrm{ml}$ of chloroform for $5 \mathrm{~min}$ at room temperature. All sections were apposed to LKB Ultrofilm for 4 weeks and subjected to densitometric analysis. This procedure has previously been shown to provide accurate estimates of autoabsorption (Geary et al., 1985).

Neuron soma density. Animals of 4 and $11 \mathrm{~d}$ were anesthetized with pentabarbitol, perfused intracardially with $10 \%$ buffered formalin, and the brain removed. The brains were embedded in paraffin and $8 \mu \mathrm{m}$ sections cut. A 1-in-4 series was mounted onto slides, then stained in $1 \%$ thionin. Soma counts were obtained by visualizing a region of the LSO with a video camera (Dage 68) mounted on a compound microscope with a $40 \times$ planapo objective. The displayed image was analyzed 

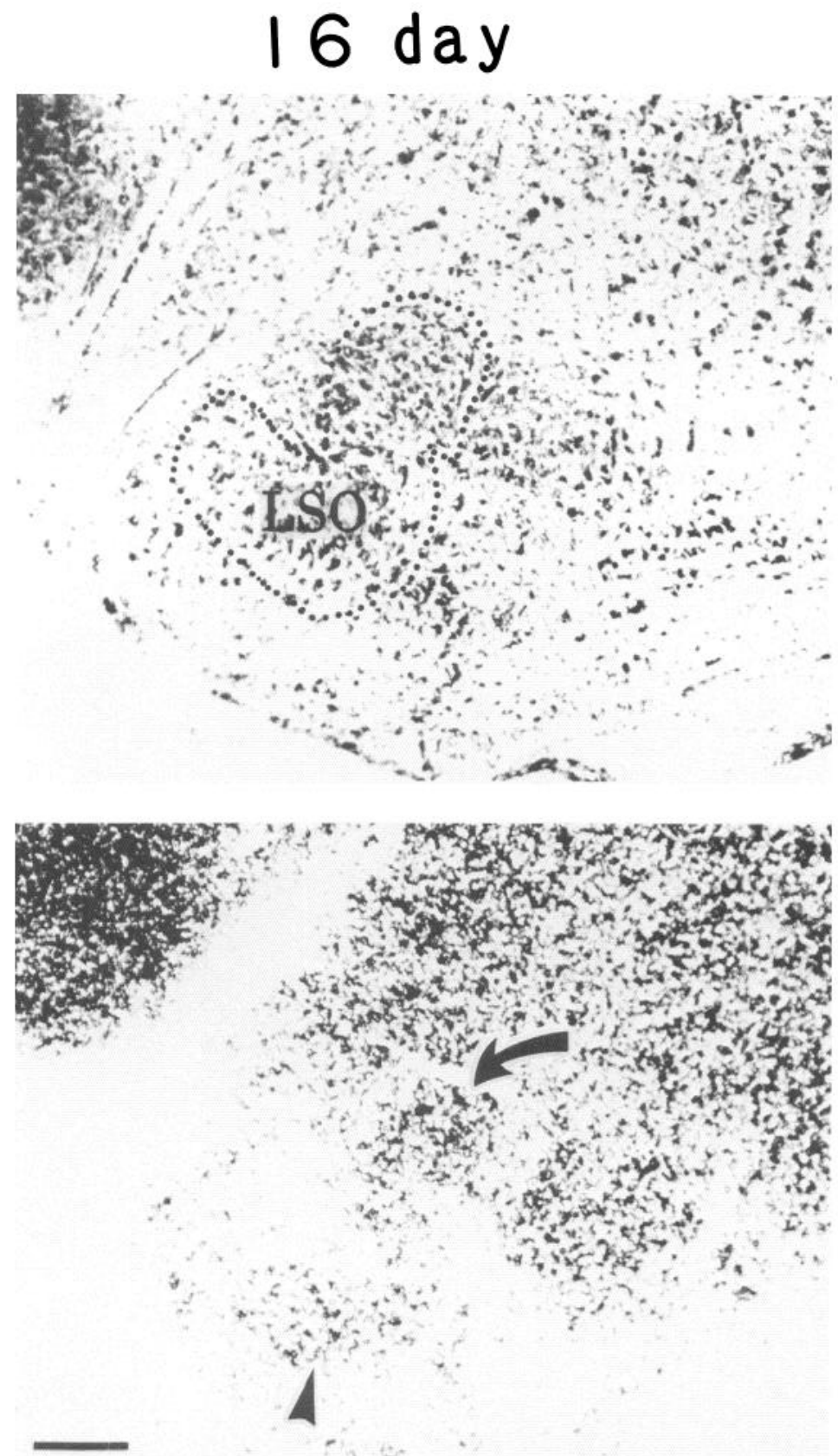

Figure 2. Representative image for ${ }^{3} \mathrm{H}$ SN binding distribution in the lateral superior olive of a $16 \mathrm{~d}$ animal. The Nissl-stained section (top) and autoradiogram of total binding (bottom) are shown. The LSO is delineated in the Nissl section. In the total-binding section, the high-frequency region (arrow) and the low-frequency region (arrowhead) are indicated. The ${ }^{3} \mathrm{H}-\mathrm{SN}$ binding distributed is not graded to the extent seen for $21 \mathrm{~d}$ animals. $L S O$, Lateral superior olive. Calibration bar, $200 \mu \mathrm{m}$.

using a Zeiss Videoplan, with counts per unit area computed and averaged. Only cells with nucleoli were counted.

\section{Results}

Autoabsorption

The ability of tissue to prevent tritium emissions from reaching the film was assayed for in the LSO (see Materials and Methods). The dorsal and ventral regions of the nucleus were examined separately, as we intended to assay glycine receptor distribution along the same axis. The values for autoabsorption in $11 \mathrm{~d}$ animals (i.e., given as the numbers by which uncorrected concentrations were multiplied) were 1.32 dorsally and 1.27 ventrically ( 2 animals; 12 measurements). The values for autoabsorption in $4 \mathrm{~d}$ animals were 1.33 dorsally and 1.43 ventrally (2 animals; 20 measurements).

\section{Quantitative autoradiograph}

Representative Nissl-stained sections with their corresponding autoradiographic images (e.g., total binding) are shown for animals aged 4, 10, 16, and $21 \mathrm{~d}$ in Figures 1-4. The section from a $21 \mathrm{~d}$ animal (Fig. 1) is quite similar in appearance to that of an adult (Sanes et al., 1987, the previous paper), displaying a markedly greater density of binding in the dorsomedial region of the LSO. While a nonuniform distribution of grains was present at $16 \mathrm{~d}$ (Fig. 2), it was not as impressive as in the $21 \mathrm{~d}$ animals. This distribution was apparently not in evidence either on day 10 (Fig. 3) or day 4 (Fig. 4).

The binding of ${ }^{3} \mathrm{H}-\mathrm{SN}$ was quantified to yield values for receptor concentration in 4 or 5 regions of the LSO along the transverse plane. The values obtained (in fmol) $(\bar{x} \pm \mathrm{SD})$ are 


\section{O day}
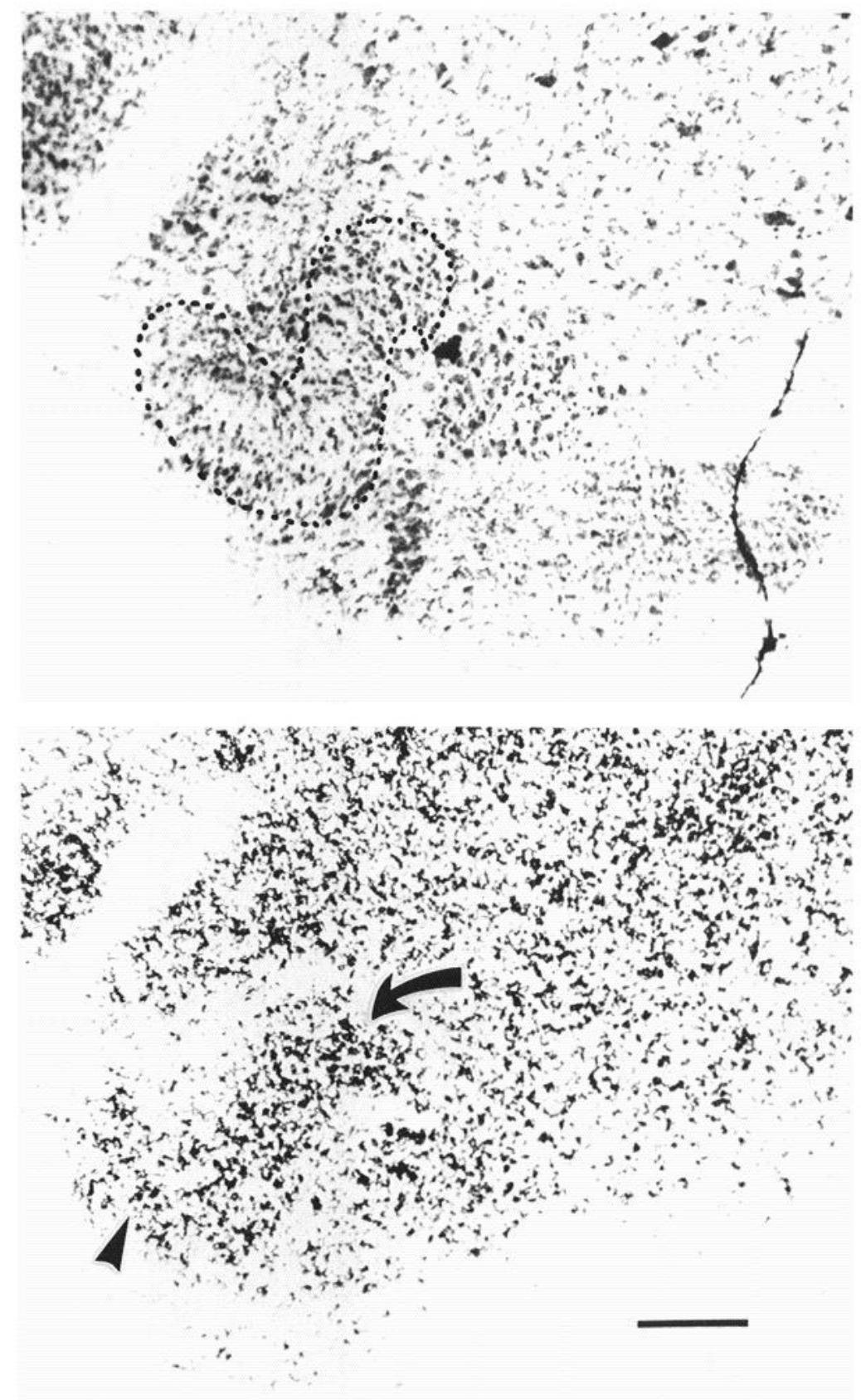

Figure 3. Representative image for ${ }^{3} \mathrm{H}$ $\mathrm{SN}$ binding distribution in the lateral superior olive of a $10 \mathrm{~d}$ animal. The Nissl-stained section (top) and autoradiogram of total binding (bottom) are shown. The LSO is delineated in the Nissl section. In the total-binding section, the high-frequency region (arrow) and low-frequency region (arrowhead) are indicated. The ${ }^{3} \mathrm{H}-\mathrm{SN}$ binding distribution is fairly uniform across the frequency axis. LSO, Lateral superior olive. Calibration bar, $200 \mu \mathrm{m}$.

listed in Table 1. For comparison, the glycine receptor concentration from adult animals is also presented (Sanes et al., 1987). The apparent concentration of receptor increased in all areas of the nucleus between 4-5 and 9-10 d. Between 9-10 and $21 \mathrm{~d}$, the receptor concentration seemed to remain relatively constant in the dorsal region of the LSO (regions 1 and 2, Table 1), while decreasing in the ventral region of the LSO (regions 3-5, Table 1). After day 21 there was a decrease in receptor concentration throughout the nucleus. These changes in concentration may be partly a reflection of the changing volume of the LSO.

The most unexpected finding was that the relative concentration of glycine receptor in the dorsal and ventral regions of the LSO changed with age. That is, a uniform distribution of
${ }^{3} \mathrm{H}-\mathrm{SN}$ binding existed in 4-5 $\mathrm{d}$ and 9-10 $\mathrm{d}$ animals, but animals in the older age groups acquired a graded distribution such that there was an approximately 4 -fold difference by $90 \mathrm{~d}$ (Table 1).

\section{Neuronal soma density}

The density of neuronal somas in specific regions of the LSO was determined for 4 and $11 \mathrm{~d}$ animals. The values for these age groups are shown along with previously obtained values from adults (preceding paper, Sanes et al., 1987) for comparison in Table 2. The number of cells per unit area decreased dramatically during postnatal maturation, presumably because of an increase in volume. At 4-5 d, there were 2025-3895 cells/ 


\section{4 day}
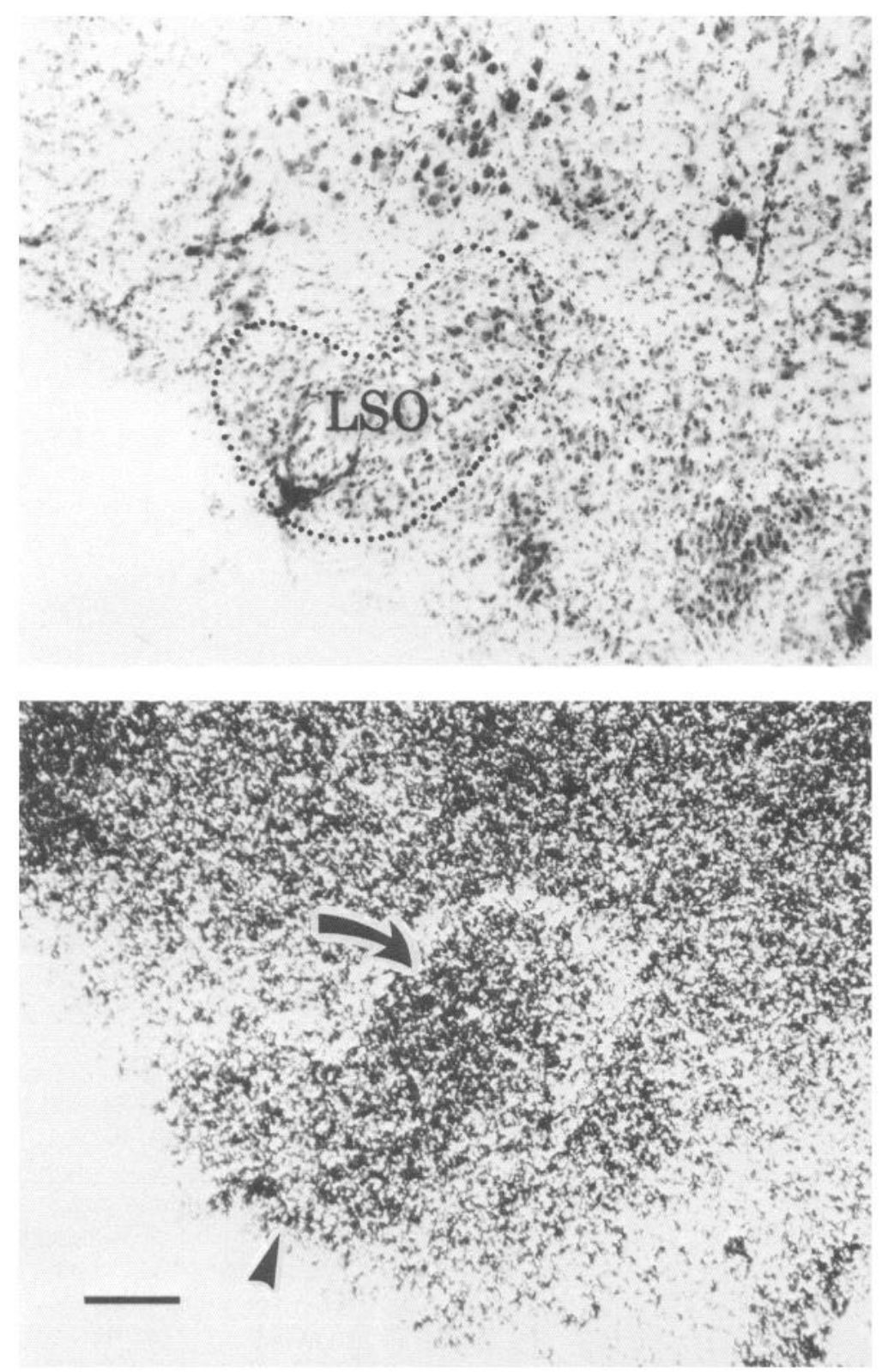

Figure 4. Representative image for ${ }^{3} \mathrm{H}$ $\mathrm{SN}$ binding distribution in the lateral superior olive of a $4 \mathrm{~d}$ animal. The Nisslstained section (top) and autoradiogram of total binding (bottom) are shown. The LSO is delineated in the Nissl section. In the total-binding section, the high-frequency region (arrow) and low-frequency region (arrowhead) are indicated. The ${ }^{3} \mathrm{H}-\mathrm{SN}$ binding distribution is nearly uniform across the frequency axis. LSO, Lateral superior olive. Calibration bar, $150 \mu \mathrm{m}$. $\mathrm{mm}^{2}$, and this range of values decreased to $366-757$ cells $/ \mathrm{mm}^{2}$ in the adult (Table 2). The difference in packing density between the dorsal (i.e., region 1) and ventral (i.e., regions 3 and 4) areas of the LSO was 2-fold in adults and 1.9-fold in the 4 and $10 \mathrm{~d}$ animals (Table 2).

The schematic in Figure 5 illustrates the developmental relationship of glycine receptor distribution, neuron density, nucleus volume, and the tonotopic axis.

\section{Discussion}

The quantitative appearance of neurotransmitter systems is currently the most informative molecular correlate of synaptogenesis. Experimental work has focused on the cellular mechanisms involved with the accumulation and localization of neuroreceptors (Zukin et al., 1975; Enna et al., 1976; Bevan and Steinbach, 1977; Burden, 1977a; Harden et al., 1977; Pardo et al., 1977; Goodman and Spitzer, 1980; Morris et al., 1980; Hays et al., 1981; Kent et al., 1982; Weiss et al., 1984), the determination of transmitter and receptor type from an initially large array (Potter et al., 1981; Bixby and Spitzer, 1982; Black et al., 1984; Doupe et al., 1985), the maturation of receptor form and function (Papanno, 1972; Burden, 1977b; Obata et al., 1978; Sakmann and Brenner, 1978; Ziskind and Dennis, 1978; Hall et al., 1983; Mueller et al., 1983), and the ontogenetic roles they may potentially have in addition to synaptic transmission (Lauder and Krebs, 1978; Woolf et al., 1979; Lauder et al., 1981; Haydon et al., 1984). The present results highlight a unique 
Table 1. Regional concentration of glycine receptors in the LSO during development and the magnitude of its graded distribution

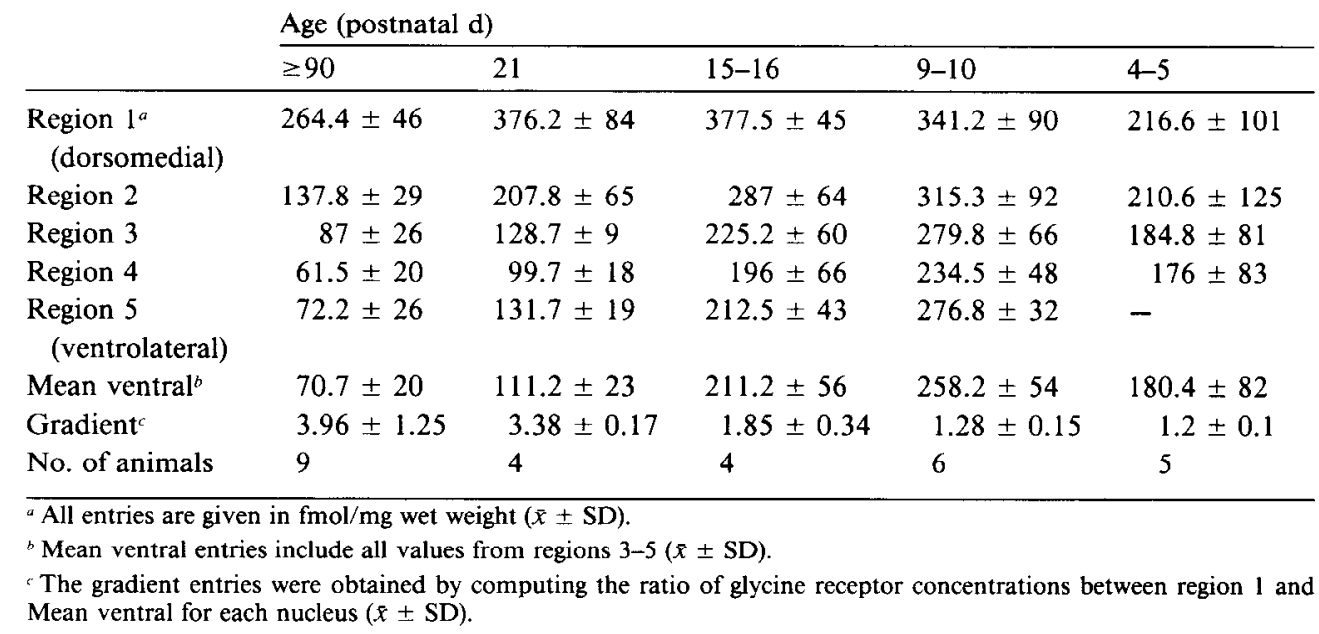

phenomenon in transmitter system development: a progressive alteration in the distribution of the glycine receptor across one axis of a central auditory nucleus.

The postnatal increase of glycine receptor concentration within the gerbil LSO was fairly uniform from days 4-5 through days 9-10. There was an apparent 50\% increase in concentration (see Table 1) at a time when there was certainly an increase in nucleus volume (D. H. Sanes, unpublished observations). An informative calculation of the actual increase in receptor number would depend on a quantitative measure of total postsynaptic neuron membrane, a value that is currently unavailable. From 9-10 d to 15-16 d, the period that includes hearing onset, there is little or no apparent increase in receptor concentration dorsally and a small decrease ventrally (Table 1). As this is also a time of nucleus volume increase (D. H. Sanes, unpublished observations), receptors must be added through this period. From 15-16 to $21 \mathrm{~d}$, there is no apparent change dorsally, but an approximately $50 \%$ decrease ventrally. This change is also accompanied by a volume increase that has not been quantified. There is a $30-45 \%$ decrease in apparent receptor concentration from 21 to $90 \mathrm{~d}$ in all regions.

\section{Table 2. Regional density of neuronal somas in the LSO during development and magnitude of its graded distribution}

\begin{tabular}{|c|c|c|c|}
\hline & \multicolumn{3}{|c|}{ Age (postnatal d) } \\
\hline & $\geq 90$ & 10 & 4 \\
\hline $\begin{array}{l}\text { Region } 1^{a} \\
\quad \text { (dorsomedial) }\end{array}$ & $757 \pm 107$ & $2612 \pm 568$ & $3876 \pm 990$ \\
\hline Region 2 & $597 \pm 153$ & $2109 \pm 527$ & $3895 \pm 1330$ \\
\hline Region 3 & $391 \pm 33$ & $1481 \pm 358$ & $2326 \pm 494$ \\
\hline $\begin{array}{l}\text { Region } 4 \\
\quad \text { (ventrolateral) }\end{array}$ & $366 \pm 51$ & $1338 \pm 304$ & $2025 \pm 537$ \\
\hline Gradient $t^{b}$ & $2.1 \pm 0.14$ & $1.9 \pm 0.1$ & $1.9 \pm 0.1$ \\
\hline No. of animals & 4 & 3 & 3 \\
\hline
\end{tabular}

\footnotetext{
${ }^{a}$ All entries are given in neurons $/ \mathrm{mm}^{2}(\bar{x} \pm \mathrm{SD})$.

"The gradicnt entrics werc obtained by computing the ratio of ncuron densitics between region 1 and region 4 for each nucleus $(\bar{x} \pm S D)$.
}

\section{Influence of nucleus volume and neuron density}

The change in volume of the LSO between 15-16 d and $90 \mathrm{~d}$ is known to be a $50 \%$ increase (D. H. Sanes, M. Merickel, and E. W. Rubel, unpublished observations). If the membrane on which glycine receptors are localized (presumably the LSO neurons) did not increase disproportionately to nucleus volume during this time, then we could estimate the actual change in receptor concentration and distribution. For the dorsalmost region (region 1 in Table 1), where apparent receptor concentration decreased by $30 \%$, the change may be entirely accounted for by the $50 \%$ increase in volume. Nevertheless, given the incongruity of the 2 measures, there may be a net increase in receptor concentration during this period. In contrast, the apparent decrease in receptor concentration ventrally (Mean ventral, Table 1) is $66 \%$. Although this apparent decrease is principally accounted for by the $50 \%$ increase in volume, there may be a net decrease in receptor concentration during this period. Therefore, as a consequence of these discordant ontogenetic courses, there appears a nonuniform distribution of glycine receptors across the transverse axis of the LSO.

The appearance of a receptor gradient was not due to an alteration in the relative distribution of neurons. Measurements of soma density along the transverse axis of LSO showed an expected decrease with age, presumably due to a concomitant increase in volume. A nonuniform distribution of neurons was found along the transverse axis of LSO at all ages examined, this being approximately 2 -fold (Table 2 ). Since the receptor distribution progresses from near-uniformity to a 4-fold gradient (Table 1), whereas there is a consistent 2-fold neuron density gradient (Table 2), the appearance of the receptor gradient is most likely due to alteration of the receptor number. It should be noted, however, that soma density is not an inclusive measure of postsynaptic membrane. Given the aforementioned influence of volume increase, it is likely that the appearance of a receptor gradient derives from a selective loss of receptors ventrally. Several neuroreceptors demonstratc a supramaximal concentration followed by a decline during postnatal development (Harden et al., 1977; Morris et al., 1980; Hays et al., 1981; Kent et al., 1982). 


\section{HEARING ONSET}
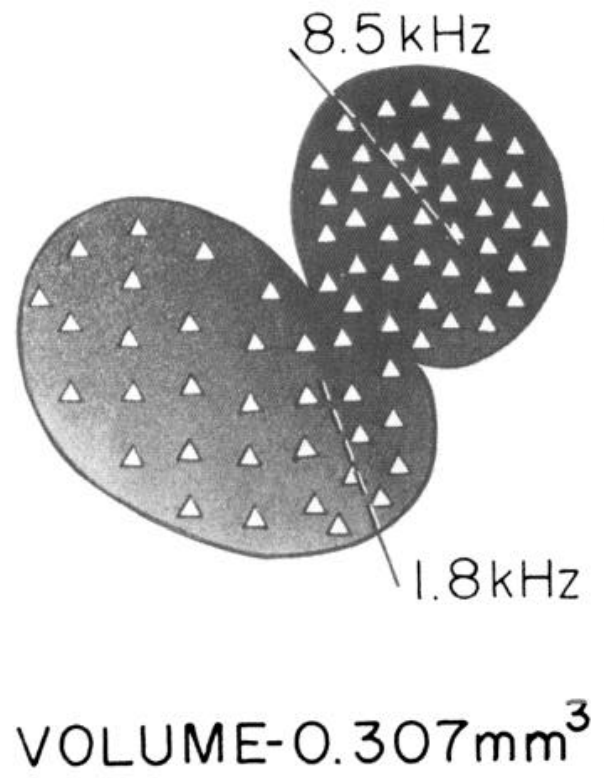

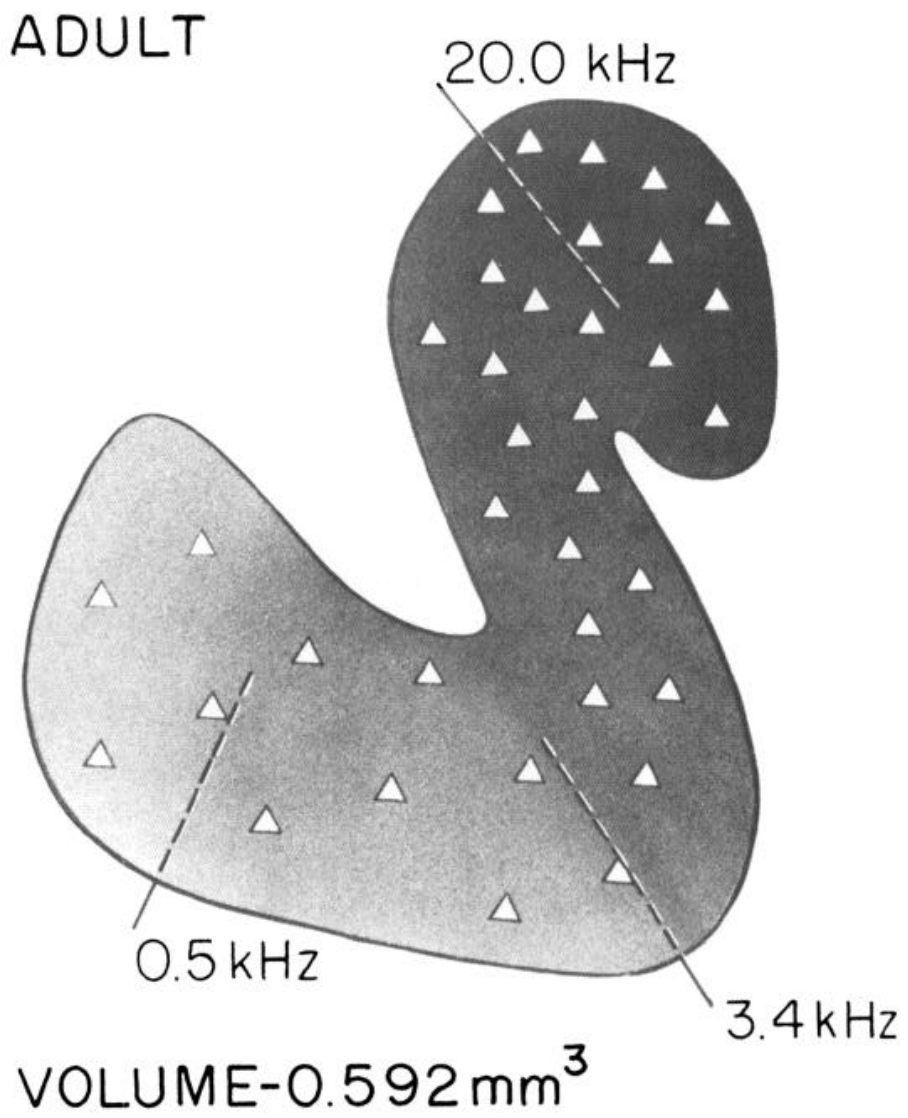

Figure 5. Summary of developmental changes in the lateral superior olive. At the onset of hearing (left), the packing density of neurons (triangles) is greater than that seen in adults, but is twice as great in the high-frequency region as in the low-frequency region. The packing density of neurons is also distributed along a 2-fold gradient in the adult (right). The concentration of glycine receptors (shading) is distributed in a 1-2-fold gradient at hearing onset (left), but is distributed in a 4-fold gradient in the adult. The frequency response of a given location in the LSO changes during this period (because of alterations in the cochlea) as indicated. The nuclear volume during this time is shown at the bottom of both schematics.

\section{Developmental correlates}

If there is an initial overproduction of glycine receptors ventrally, then one must determine the developmental constraints under which they are eliminated. Although we are at present unable to explain this phenomenon, there are several findings that may guide future study. Three possible scenarios are discussed in this section.

The appearance of the receptor gradient takes place along the axis of most obvious functional relevance, the cochleotopic axis (Tsuchitani and Boudreau, 1966; D. H. Sanes, M. Merickel, and E. W. Rubel, unpublished observations). There is also known to be a temporal pattern of neurogenesis along the cochleotopic axis of the rat LSO, such that high-frequency neurons (i.e., those in the dorsomedial region) are the first generated (Altman and Bayer, 1980). One possibility, then, might be that neurons within the LSO proceed through different ontogenetic programs by virtue of their cell lineage. The relationship between cell lineage and phenotype has been well-documented in several systems, particularly for invertebrates (Goodman and Spitzer, 1979; Weisblat et al., 1980; White et al., 1982; Herrup et al., 1984).

A second possibility is that the number of glycine receptors is a reflection of a transient afferent projection to the ventral LSO. It has been found that within the adult LSO, there is a nonuniform distribution of terminal arbors from neurons in the MNTB, such that the arborization is denser in the high-fre- quency dorsomedial region (Glendenning et al., 1985). It will be of interest to determine the initial projection pattern of the MNTB neurons, since neuroreceptor accumulation is responsive to the presence of afferent terminals (Cohen et al., 1979; Frank and Fischbach, 1979).

Finally, it is worth considering the probable sequence of electrical activity within the developing LSO. The initial range of frequencies that elicits a response from gerbil central neurons is limited (Woolf and Ryan, 1985), although the frequency range of the cochlea resembles the adult at hearing onset (Woolf and Ryan, 1984). At early ages (i.e., 14-18 d after birth), there is greater sound-evoked metabolic activity in the high-frequency region of the inferior colliculus than in the low-frequency region (Ryan et al., 1982). During this same period, spatial frequency maps of the cochlea change, so that a given place transduces successively higher frequencies (Harris and Dallos, 1984; D. H. Sanes, M. Merickel, and E. W. Rubel, unpublished observations). Two electrophysiological studies have found the lowerfrequency regions of a brain stem auditory nucleus to yield very few responsive neurons (Lippe and Rubel, 1985; D. H. Sanes, M. Merickel, and E. W. Rubel, unpublished observations). Together, these findings suggest that neurons in the region of LSO that exhibit transiently high levels of SN binding may be temporarily subject to lower levels of afferent activity at the time of hearing onset. Should the level of afferent activity be a causative influence on the receptor number, this would imply that 
synaptic quiescence is particularly disadvantageous for the inhibitory glycinergic synapse. It is of great interest, then, to determine whether a similar ontogenetic pattern obtains for the excitatory neuroreceptor. As this latter scenario is highly speculative and without experimental precedent, we consider it to be the least likely alternative.

This report has documented the temporal increase of glycine receptors in the gerbil LSO. There was a large increment of receptor concentration throughout the nucleus during the first 10 postnatal $\mathrm{d}$. After this point, the dorsal and ventral regions of the nucleus adopted alternative ontogenetic patterns. Whereas receptor number continued to increase dorsally between 910 and $90 \mathrm{~d}$, the concentration of receptor apparently decreased ventrally. Thus, a nonuniform distribution of glycine receptors gradually appeared across the tonotopic axis of the LSO.

\section{References}

Altman, J., and S. A. Bayer (1980) Development of the brain stem in the rat. III. Thymidine-radiographic study of the time of origin of neurons of the vestibular and auditory nuclei of the upper medulla. J. Comp. Neurol. 194: 877-904.

Bevan, S., and J. H. Steinbach (1977) The distribution of $\alpha$-bungarotoxin binding sites on mammalian skeletal muscle developing in vivo. J. Physiol. (Lond.) 267: 195-213.

Bixby, J. L., and N. C. Spitzer (1982) The appearance and development of chemosensitivity in Rohon-Beard neurones of the Xenopus spinal cord. J. Physiol. (Lond.) 330: 513-536.

Black, I. B., J. E. Alder, M. C. Bohn, G. M. Jonakait, J. A. Kessler, and K. A. Markey (1984) Transmitter phenotypic plasticity in developing and mature neurons in vivo. In Cellular and Molecular Biology of Neuronal Development, I. B. Black, ed., pp. 117-130, Plenum, New York.

Boudreau, J. C., and C. Tsuchitani (1968) Binaural interaction in the cat superior olive S-segment. J. Neurophysiol. 31: 442-454.

Burden, S. (1977a) Development of the neuromuscular junction in the chick embryo: The number, distribution, and stability of acetylcholine receptors. Dev. Biol. 57: 317-329.

Burden, S. (1977b) Acetylcholine receptors at the neuromuscular junction: Developmental change in receptor turnover. Dev. Biol. 61:7985.

Campistron, G., R. Buijs, and M. Geffard (1986) Glycine neurons in the brain and spinal cord. Antibody production and immunocytochemical localization. Brain Res. 376: 400-405.

Cohen, M. W., M. J. Anderson, E. Zorychta, and P. R. Weldon (1979) Accumulation of acetylcholinc receptors at nerve-muscle contacts in culture. Prog. Brain Res. 49: 335-349.

Curtis, D. R., A. W. Duggan, and G. A. R. Johnston (1971) The specificity of strychnine as a glycine antagonist in the mammalian spinal cord. Exp. Brain Res. 12: 547-565.

Doupe, A. J., P. H. Patterson, and S. C. Landis (1985) Small intensely fluorescent cells in culture: Role of glucocorticoids and growth factors in their development and interconversions with other neural crest derivatives. J. Neurosci. 5: 2143-2160.

Enna, S. J., H. I. Yamamura, and S. H. Snyder (1976) Development of muscarinic, cholinergic, and GABA receptor binding in chick embryo brain. Brain Res. 101: 177-183.

Frank, E., and G. D. Fischbach (1979) Early events in neuromuscular junction formation in vitro: Induction of acetylcholine receptor clusters in the postsynaptic membrane and morphology of newly formed synapses. J. Cell Biol. 83: 143-158.

Geary, W. A., A. W. Toga, and G. F. Wooten (1985) Quantitative film autoradiography for tritium: Methodological considerations. Brain Res. 337: 99-108.

Glendenning, K. K., K. A. Hutson, R. J. Nudo, and R. B. Masterton (1985) Acoustic chiasm II. Anatomical basis of binaurality in lateral superior olive of cat. J. Comp. Neurol. 232: 261-285.

Goodman, C. S., and N. C. Spitzer (1979) Embryonic development of identified neurones: Differentiation from neuroblast to neurone. Nature 280: 208-214.

Goodman, C. S., and N. C. Spitzer (1980) Embryonic development of neurotransmitter receptors in grasshoppers. In Receptors for $\mathrm{Neu}$ - rotransmitters, Hormones, and Pheromones in Insects, D. B. Satelle L. M. Hall, and J. G. Hildebrand, eds., pp. 195-207, Elsevier, Amsterdam.

Hall, Z. W., M. P. Rosin, Y. Gu, and P. D. Gorin (1983) A developmental change in the immunological properties of acetylcholine receptors at the rat neuromuscular junction. Cold Spring Harbor Symp. Quant. Biol. 48: 101-108.

Harden, T. K., B. B. Wolfe, J. R. Sparn, J. P. Perkins, and P. B. Molinoff (1977) Onotgeny of $\beta$-adenergic receptors in rat cerebral cortex. Brain Res. 125: 99-108.

Harris, D. M., and P. Dallos (1984) Ontogenetic changes in frequency mapping of a mammalian ear. Science 225: 741-743.

Haydon, P. G., D. P. McCobb, and S. B. Kater (1984) Serotonin selectively inhibits growth cone motility and synaptogenesis of specific identified neurons. Science 226: 561-564.

Hays, S., S. H. Houston, M. C. Beinfeld, and S. M. Paul (1981) Postnatal ontogeny of cholecystokinin receptors in rat brain. Brain Res. 213: 237-241.

Herrup, K., T. J. Diglio, and A. Letson (1984) Cell lineage relationships in the development of the mammalian CNS I. The facial nerve nucleus. Dev. Biol. 103: 329-336.

Kent, J. L., C. B. Pert, and M. Herkenham (1982) Ontogency of opiate receptors in rat forebrain: Visualization by in vitro autoradiography. Dev. Brain Res. 2: 487-504.

Lauder, J. M., and H. Krebs (1978) Seritonin as a differentiation signal in early neurogenesis. Dev. Neurosci. 1: 15-30.

Lauder, J. M., J. A. Wallace, and H. Krebs (1981) Roles for seritonin in neuroembryogenesis. Adv. Exp. Med. Biol. 133: 477-506.

Lippe, W., and E. W. Rubel (1985) Ontogeny of tonotopic organization of brainstem auditory nuclei in the chicken: Implications for development of the place principle. J. Comp. Neurol. 237: 273-289.

Moore, M. J., and D. M. Caspary (1983) Strychnine blocks binaural inhibition in lateral superior olivary neurons. J. Neurosci. 3: 237247.

Morest, D. K., and M. Jean-Baptiste (1975) Degeneration and phagocytosis of synaptic endings and axons in the medial trapezoid nucleus of the cat. J. Comp. Neurol. 162: 135-156.

Morris, M. J., J. P. Dausse, M. D. Devynck, and P. Meyer (1980) Ontogeny of $\alpha_{1}$ - and $\alpha_{2}$-adrenoceptors in rat brain. In Biogenic Amines in Development, H. Parvez and S. Parvez, eds., pp. 241-261, Elsevier, Amsterdam

Mueller, A. G., R. M. Chesnut, and P. A. Schwartzkroin (1983) Actions of GABA in developing rabbit hippocampus: An in vitro study. Neurosci. Lett. 39: 193-198.

Obata, K., M. Oide, and H. Tanaka (1978) Excitatory and inhibitory actions of GABA and glycine on embryonic chick spinal neurons in culture. Brain Res. 144: 179-184.

Papanno, A. J. (1972) Sodium-dependent depolarization of noninnervated embryonic chick heart by acetylcholinc. J. Pharmacol. Exp. Ther. 180:340-350.

Pardo, J. V., I. Creese, D. R. Burt, and S. H. Snyder (1977) Ontogenesis of dopamine receptor binding in the corpus striatum of the rat. Brain Res. 125: 376-382.

Potter, D. D., S. C. Landis, and E. J. Furshpan (1981) Adrenergiccholinergic dual function in cultured sympathetic neurons of the rat. In Development of the Autonomic Nervous System, K. Elliott and G. Lawrensen, eds., pp. 123-138 (Ciba Foundation Symposium 83), Pittman, London.

Purves, D., and J. W. Lichtman (1985) Principles of Neural Development, Sinaur, Sunderland, MA.

Ryan, A. F., N. K. Woolf, and F. R. Sharp (1982) Functional ontogeny in the central auditory pathway of the mongolian gerbil. Exp. Brain Res. 47: 428-436.

Sakmann, B., and H. R. Brenner (1978) Change in synaptic channel gating during neuromuscular development. Nature 276: 401-402.

Sanes, D. H., W. A. Geary, and G. F. Wooten (1985) The quantitative distribution of ${ }^{3} \mathrm{H}$-strychnine binding in the lateral superior olivary nucleus of the gerbil. Soc. Neurosci. Abstr. 15: 1051 .

Sanes, D. H., W. A. Geary, G. F. Wooten, and E. W. Rubel (1987) Quantitative distribution of the glycine receptor in the auditory brain stem of the gerbil. J. Neurosci. 7: 3793-3802.

Sanes, D. H. and E. W. Rubel (in press) The ontogeny of inhibition and excitation in the gerbil lateral superior olive. J. Neurosci.

Schwart7, I. (1985) Autoradiographic studies of amino acid labeling of neural elements in the auditory brainstem. In Auditory Biochem- 
istry, D. G. Drescher, ed., pp. 258-277, Thomas, Springfield, MA.

Spangler, K. M., W. B. Warr, and C. K. Henkel (1985) The projections of the principal cells of the medial nucleus of the trapezoid body in the cat. I. Comp. Neurol. 238: 249-262.

Tsuchitani, C., and J. C. Boudreau (1966) Single unir analysis of cat superior olivary complex. J. Neurophysiol. 40: 296-318.

Weisblat, D. A., G. Harper, G. S. Stent, and R. T. Sawyer (1980) Embryonic cell lineages in the nervous system of the glossiphoniid leach, Helobdella triserialis. Dev. Biol. 76: 58-78.

Weiss, B., M. B. Clark, and L. H. Greenberg (1984) Modulation of catecholaminergic receptors during development and aging. In $\mathrm{Hand}$ book of Neurochemistry, vol. 6: Receptors in the Nervous System, A. Lajtha, ed., pp. 595-627, Plenum, New York.

White, J. G., R. H. Horvitz, and J. E. Sulston (1982) Neurone differentiation in cell lineage mutants of Caenorhabditis elegans. Nature 297: 584-587.

Woolf, J. R., F. Joó, W. Dames, and O. Fehér (1979) Induction and maintenance of free postsynaptic membrane thickenings in the adult superior cervical ganglion. J. Neurocytol. 8: 549-563.
Woolf, N. K., and A. F. Ryan (1984) The development of auditory function in the cochlea of the mongolian gerbil. Hear. Res. 13: 277283.

Woolf, N. K., and A. F. Ryan (1985) Ontogeny of neural discharge patterns in the ventral cochlear nucleus of the mongolian gerbil. Dev. Brain Res. 17: 131-147.

Young, A. B., and S. H. Snyder (1973) Strychnine binding associated with glycine receptors of the central nervous system. Proc. Natl. Acad. Sci. USA 70: 2832-2836.

Zarbin, M. D., J. K. Wamsley, and M. J. Kuhar (1981) Glycine receptor: Light microscopic autoradiographic localization with $\left[{ }^{3} \mathrm{H}\right]-$ strychnine. J. Neurosci. 1: 532-547.

Ziskind, L., and M. J. Dennis (1978) Depolarizing effect of curare on embryonic rat muscles. Nature 276: 622-623.

Zukin, S. R., A. B. Young, and S. H. Snyder (1975) Development of the synaptic glycine receptor in chick embryo spinal cord. Brain Res. 83: $525-530$. 